\title{
The Molecular Adsorbents Recycling System as a Liver Support System Based on Albumin Dialysis: A Summary of Preclinical Investigations, Prospective, Randomized, Controlled Clinical Trial, and Clinical Experience from 19 Centers
}

\author{
*Jan Stange, *Tarek I. Hassanein, $†$ Ravindra Mehta, $\ddagger$ Steffen R. Mitzner, and \\ $\S$ Robert H. Bartlett \\ *Division of Gastroenterology, Hepatology; †Division of Nephrology, UCSD Medical Center, San Diego, California, \\ U.S.A.; $\$$ Division of Nephrology, Department of Internal Medicine, University of Rostock, Rostock, Germany; and \\ $\S$ Department of Surgery, University of Michigan Hospitals, Ann Arbor, Michigan, U.S.A.
}

\begin{abstract}
Artificial liver support aims to prolong survival time of patients with liver failure by detoxification. Albumin as a molecular adsorbent in dialysis solution is capable of attracting even tightly albumin-bound toxins from blood into the dialysate if a specific dialysis membrane is used and if the albumin's binding sites are on-line-purified by a sorbent/dialysis-based recycling system (i.e., molecular adsorbents recycling system, or MARS). The MARS technology has been shown to remove water-soluble and albumin-bound toxins and to provide renal support in case of renal failure. Fourteen centers have reported that MARS treatment improved mental status of patients with liver failure and hepatic encephalopathy. In treating liver fail-
\end{abstract}

ure and cholestasis, MARS was associated with hemodynamic stabilization, improvement of hepatic and kidney function, and disappearance of pruritus. In hepatic failure and hepatorenal syndrome, a prospective, randomized, controlled trial of MARS treatment was able to prolong survival time significantly. MARS has been used in 26 patients with acute liver failure or primary graft dysfunction. Nineteen centers reporting on 103 patients have shown that MARS treatment is safe, easy to handle, feasible, and effective. Key Words: Albumin dialysis-Clinical trials-Liver failure-Liver support-Molecular adsorbents recycling system-Multicenter trials.
Hepatic failure is a clinical syndrome that results from loss of functional liver cell mass below a critical level. This may be due to toxic-, viral-, or ischemicinduced massive hepatocyte necrosis in a formerly healthy liver causing acute liver failure, or it may be due to a precipitating event that complicates chronic liver disease in a patient with already limited functional hepatic capacity. The latter is acute decompensation of chronic liver disease and is called acute on chronic liver failure. As a result, the major liver

Received February 2001; revised September 2001.

Presented in part on the 65th birthday of Prof. Dr. Horst Klinkmann, on May 7, 2000, in Rostock, Germany.

Address correspondence and reprint requests to Dr. Jan Stange, Liver Center, UCSD Medical Center, 200 West Arbor Drive, San Diego, CA 92103-8413, U.S.A. E-mail: jan.stange@ med.uni-rostock.de functions, particularly detoxification, synthetic functions, and metabolic regulation will be impaired to different degrees, and as such, perpetuate each other. The imbalance between the physiological needs and the functions provided by the injured liver results in major life-threatening complications of liver insufficiency such as hepatic encephalopathy and coma, jaundice and cholestasis, ascites, renal failure, bleeding, immune disorders, and sepsis.

The current standard medical therapy (SMT) involves measures to treat complications and prevent further deterioration until the precipitating event can be managed in case of acute on chronic liver failure or the liver spontaneously recovers as a possible outcome in acute liver failure. Failure of these attempts leaves liver transplantation as the only viable treatment option. However, orthotropic liver 
transplant is not readily available for most patients due to the shortage in cadaveric organs.

The management of the precipitating event of liver failure until enough liver cells can help regain its function, regenerate, or an organ becomes available for transplant, requires time. Hence, time remains the crucial factor in successfully managing liver failure. Liver support technology is evolving as different techniques to assist the remaining functional cell mass by providing specific liver functions become available. The major objective of liver support is buying time.

Earlier attempts to provide liver support included the use of several extracorporeal detoxification procedures such as hemofiltration or hemodialysis, plasma exchange, and hemoperfusion or plasma perfusion using charcoal- or polymer-based sorbents.

These procedures proved to be safe, particularly hemofiltration, which had beneficial effects in some patients with hepatic encephalopathy. However, they were not significantly effective in removing albumin-bound toxic molecules due to their high binding affinity to albumin and to their inability to permeate dialysis membranes (1).

Plasma exchange was associated with major side effects that prevented the extended use that would be necessary for effective detoxification (2).

The use of nonspecific sorbents such as charcoal or ion exchangers in direct contact with blood or plasma resulted in effective removal of toxic molecules, but was also complicated by bioincompatibility, which resulted in alarming drops in fibrinogen, and by activation of complements, which resulted in systemic inflammatory response (2-4). In addition, the direct contact between sorbents and plasma proteins has been shown to result in removal of hepatocyte growth factor (5) and a number of hormones such as growth hormone (3), triiodothyronine $\left(\mathrm{T}_{3}\right)$, tetraiodothyronine $\left(\mathrm{T}_{4}\right),(3,6-8)$, parathormone $(9)$, testosterone, steroid hormones, and insulin $(3,10,11)$.

Attempts to reduce these unwanted effects of direct contact between sorbents and plasma proteins involved the use of membranes that separate blood and the unspecific sorbent. One membrane used is a cellulose flat membrane that has a similar permeability to that of a standard low-flux cellulose dialyzer (12). Although it improved hepatic encephalopathy in some patients, it does not allow removal of the albumin-bound fraction of toxic molecules. In fact, bilirubin, which is a marker for albumin-bound toxins, increased during the treatment using this membrane (13).

Another membrane used had a pore size large enough to allow albumin as the toxin carrier to pass through, but had a lower sieving coefficient for large plasma proteins such as immunoglobulin M (IgM) (14). Furthermore, as many valuable molecules have a molecular weight close to albumin, there is a loss of valuable substances such as immunoglobulin G ( sieving coefficient $>70 \%$ ), high-density lipoprotein (sieving coefficient 65\%), and fibrinogen (sieving coefficient $17 \%$ ) (14). Studies regarding the loss of other molecules that have similar molecular size to albumin, such as antithrombin III, transthyretin, transcortin, and so forth, and which also have high sieving coefficients, have not yet been published. Using this type of fractionated plasma separation in vivo resulted in a drop of serum bilirubin and an improvement of hepatic encephalopathy (13).

Thus, plasmasorption using albumin-permeable membranes to filtrate plasma or plasma fractions in order to perfuse it over unspecific sorbents to remove protein-bound toxins was not efficient in the management of liver failure in prospective, controlled randomized studies.

Recent developments have focused on the use of liver cells in extracorporeal systems to improve and substitute some of the liver functions during acute liver failure. As adult human hepatocytes cannot be produced in culture in adequate amounts, different systems use porcine hepatocytes (15) or human hepatoma cells (16). Two of these systems are currently being tested for their efficacy on patients with acute liver failure.

The goal of removing albumin-bound toxic molecules that accumulate in liver failure in an effective but also selective biocompatible manner has not been achieved with current conventional methods.

\section{THE METHOD OF ALBUMIN DIALYSIS}

Albumin dialysis is a new method that combines the efficacy of sorbents to remove albumin-bound molecules with the biocompatibility of the modern dialysis membrane. It is selective in removing protein-bound molecules that use albumin as a specific toxin carrier in human blood. Thus, albumin dialysis is an extracorporeal liver support system based on the concept of dialysis, using a specific membrane (Teraklin AG, Rostock, Germany, cut-off 50,000, sieving coefficient for albumin less than 0.01) and albumin as the dialysate. The albumin acts as a specific molecular adsorbent that is regenerated on-line by recirculating in a recycling system (i.e., molecular adsorbents recycling system, or MARS, trademark of Teraklin AG, Rostock, Germany). Due to the attracting effect of albumin, the system achieves high clearance of albumin-bound substances such as bile 
acids and bilirubin, which are not removed by hemofiltration. The membrane used in MARS is capable of releasing the albumin-ligand complex present in the blood due to its physicochemical ability to interact with lipophilic binding domains. The membrane itself is impermeable to albumin and other valuable proteins such as hormones, clotting factors, and antithrombin III and is highly tolerated in clinical use. The two sorbent columns and the dialyzer allow the removal of both protein-bound and water-soluble toxins, thus making the system useful for patients with liver failure complicated by renal insufficiency. Furthermore, additional organ support is provided by maintaining electrolyte, acid/base, fluid balance, glucose level, and by removing ammonia, a watersoluble toxin that accumulates in liver failure.

In summary, the membrane is biocompatible, which ensures a safe long-term use with no or minimal need of anticoagulation and with minimal effect on blood cell counts, platelets, and the complement system.

\section{RESULTS FROM LABORATORY INVESTIGATIONS}

\section{Proof of concept}

In laboratory investigations, it has been shown by several groups that even tightly albumin-bound molecules such as unconjugated bilirubin can be removed by dialysis using specific albuminimpermeable dialysis membranes and an albumincontaining dialysate solution (17-20). In vitro investigations using fluorescence-labeled albumin have shown that toxins travel across the membrane, reaching the dialysate solution where they are bound by albumin (21). The driving force for the mass transport of albumin-bound molecules from the blood through the membrane is the greater availability of free binding sites of the highly purified albumin in the dialysate compartment (22).

\section{Known protein-bound substances cleared by the MARS system}

In 8 consecutive patients receiving 1 single treatment of MARS, the mean reduction of serum bilirubin as a marker for albumin-bound molecules was $35 \%$ compared to baseline (23). This was superior to the reduction rates $(24 \%)$ reported by albuminpermeable membranes in fractionated plasmapheresis in vivo (13).

Furthermore, dialysis using this type of membrane and albumin in the dialysate solution increased the removal of a number of substances having a high albumin affinity including bile acids (24), benzodiazepines (25), copper (26), middle-chain fatty acids
(27), arachidonic acid (28), tryptophane (21), IL-6 (29), and TNF- $\alpha$ (29). In addition, reduction of aromatic amino acids associated with an increase of branched-chain amino acids was observed in patients with liver failure who were treated with MARS (21).

\section{Known water-soluble substances cleared by the MARS system}

MARS involves an actual dialysis circuit containing albumin which allows the system to function as hemofiltration. This property is effective in clearing serum ammonia $(24,30)$, creatinine (24), and urea (24) at certain flow rates.

\section{Impact on valuable molecules}

The plasma levels of proteins with a molecular weight close to albumin, such as antithrombin III, transferrin, thyroglobulin, and $\alpha_{1}$-antitrypsin, did not change during the treatment $(21,24)$. Other physiologically valuable substances bound to transport proteins other than albumin, such as $T_{3}$ and $T_{4}$, which are bound to thyroxin-binding globulin, also were unchanged (21).

\section{Laboratory animal evaluation}

Awad and colleagues (31) evaluated the MARS concept in an animal model of cholestatic liver failure. Dogs were studied 1 week after portocaval shunt and bile duct ligation which caused parenchymal injury and excretory failure (32). A $6 \mathrm{~h}$ treatment with MARS hemodiafiltration decreased bilirubin, ammonia, and aromatic amino acids.

\section{RESULTS FROM CLINICAL TRIALS}

\section{Results in chronic liver disease complicated by hepatorenal syndrome}

Two centers participated in the first prospective, randomized controlled trial to investigate the influence of albumin dialysis using MARS in patients suffering from end-stage liver disease and hepatorenal syndrome Type-I (33). A summary of baseline parameters and results is given in Table 1. All patients were Child Turquotte Class $\mathrm{C}$ and had elevated serum bilirubin (mean serum bilirubin $>20 \mathrm{mg} / \mathrm{dl}$ ). All 13 patients were oliguric or anuric and had a urine sodium $<20 \mathrm{mmol} / \mathrm{L}$, despite having adequate intravascular volume (CVP $10 \mathrm{~mm} \mathrm{Hg})$. Patients were randomized to standard medical therapy including hemodiafiltration or MARS treatment. MARS treatment was well tolerated and resulted in a significant removal of bilirubin as a marker for albumin-bound molecules. Furthermore, kidney function and creatinine levels also improved significantly in the MARS group compared to the control group. Associated with all these physiological improvements, a prolon- 
TABLE 1. A summary of clinical baseline and results of a prospective, randomized, controlled two-center trial in liver failure complicated by hepatorenal syndrome (31)

\begin{tabular}{|c|c|c|c|}
\hline \multicolumn{3}{|c|}{ Control group } & \multirow[t]{2}{*}{ MARS group } \\
\hline Baseline & & & \\
\hline Mean urine output & & $<500$ ml/day; NS & \\
\hline Mean CVP & & $>10 \mathrm{~mm} \mathrm{H}_{2} \mathrm{O} ; \mathrm{NS}$ & \\
\hline Mean CTP & & $>12$; NS & \\
\hline Mean serum bilirubin & & $>20 \mathrm{mg} / \mathrm{dl} ; \mathrm{NS}$ & \\
\hline Mean PT value (Quick) & & $<40 \%$; NS & \\
\hline Mean age & & $<50$ years old; NS & \\
\hline Gender & & $4 / 6$ female/male; NS & \\
\hline \multicolumn{4}{|l|}{ Results } \\
\hline \multicolumn{4}{|l|}{ MAP } \\
\hline Before & & MAP $<70 \mathrm{~mm} \mathrm{Hg}, \mathrm{NS}$ & \\
\hline After & $<60 \mathrm{~mm} \mathrm{Hg}$ & $\mathrm{p}<0.05$ & $>80 \mathrm{~mm} \mathrm{Hg}$ \\
\hline \multicolumn{4}{|l|}{ Creatinine } \\
\hline Before & & $>3 \mathrm{mg} / \mathrm{dl}, \mathrm{NS}$ & \\
\hline After & $>3 \mathrm{mg} / \mathrm{dl}$ & $\mathrm{p}<0.05$ & $<3 \mathrm{mg} / \mathrm{dl}$ \\
\hline PT value after treatment & Not significantly changed & & Significantly increased \\
\hline Bilirubin after treatment & Not significantly changed & & Significantly reduced \\
\hline Survival time analyis & $<7$ days & & Significant prolongation in survival time $(\mathrm{p}<0.05)$ \\
\hline
\end{tabular}

gation in survival time was achieved in the MARS group and was statistically significant (Table 1). The hemodynamic effects of the MARS treatment in end-stage liver disease were investigated in another trial (23). Eight patients suffering from acute decompensation of chronic liver disease received a single MARS treatment. All patients were Child Turcotte Class $\mathrm{C}$ and had a serum bilirubin higher than 15 $\mathrm{mg} / \mathrm{dl}$. Five patients had hepatorenal syndrome as well. After the treatment, the mean bilirubin was reduced to $65.4 \%$ and creatinine to $48.4 \%$ compared to baseline. There was a statistically significant improvement in the mean arterial pressure resulting from an increase of systemic vascular resistance (23). The hemodynamic improvement was associated with the reduction in plasma renin activity (23).

\section{Results in chronic liver disease complicated by cholestasis}

Because MARS has the ability to clear bilirubin and bile acids, it was used in patients with end-stage liver disease (ESLD) and cholestasis (34). Twentysix consecutive patients with ESLD and cholestasis were included in the study after an initial trial of SMT without improvement. Their serum bilirubin was higher than $15 \mathrm{mg} / \mathrm{dl}$, and 23 patients had hepatic encephalopathy, 11 had refractory ascites, 14 had hepatorenal syndrome, and 23 had detectable infections. Patients received treatments every day or every other day depending on a patient's condition. The mean number of treatments was 5.5 per patient. A $6 \mathrm{~h}$ MARS treatment resulted in significant reduction of serum bile acid and serum bilirubin levels. There was significant improvement in hepatic en- cephalopathy, and all patients on MARS had an improvement in their Child Turquotte Pugh score.

Similar findings were reported by another group that studied patients with ESLD and acute decompensation presenting with hepatic encephalopathy (35). The group reported reduction of serum bilirubin and ammonia levels and a considerable neurological improvement in all patients. Using central venous monitoring, they also confirmed an increase in systemic vascular resistance associated with an increase of mean arterial pressure.

\section{Results in acute liver failure}

A phase-I pilot study using MARS in acute liver failure as a bridge to liver transplant is actively recruiting patients (36). Preliminary data show that the procedure is well tolerated, the serum ammonia level decreased significantly, hepatic coma score improved, and the ratio between branched-chain and aromatic amino acids increased significantly. In addition, there was a significant increase in clotting factor VII as a marker for hepatocyte synthetic function. Of the 5 patients enrolled in this study who were United Network Organ Sharing (UNOS) status 1,1 patient recovered his native hepatic function, and 3 patients were successfully bridged to transplantation. It is worth mentioning that one of the patients who was retransplanted was anhepatic and on MARS therapy for $70 \mathrm{~h}$.

In another center using MARS in fulminant hepatitic failure, 4 patients were bridged until a transplant became available (37). This center's experience confirmed significant reduction of serum ammonia and bilirubin and neurological improvement.

Two cases with fulminant Wilson disease $(26,38)$ 
complicated by renal failure, toxic hemolysis, and hepatic encephalopathy were treated with albumin dialysis. Both patients recovered at 3 and 8 weeks, respectively, and were transplanted. The copper removal rate obtained by MARS exceeded the removal rate obtained by plasma exchange, and the renal excretion of penicillamine was used as chelator (23).

Another center reported the use of MARS in a 49-year-old patient suffering from fulminant liver failure due to acetaminophen toxicity (39). The patient had hepatic coma, increased intracranial pressure, and severe coagulopathy (INR 4.1). She was listed for liver transplantation status 1 . Her course was complicated by kidney failure, acidosis, and severe hypoglycemia. MARS treatment was initiated to keep the patient alive until a liver for transplant became available. Reduction of intracranial pressure and improvement of neurological function and hemodynamic status was observed within the first $24 \mathrm{~h}$ after the start of treatment. After 3 days on MARS, the patient's liver function improved, and MARS was stopped. The patient recovered without need of transplantation (39).

\section{Results in primary graft dysfunction}

MARS therapy has been used in the treatment of primary graft dysfunction complicating split liver transplantation. In one center out of 4 grafts with primary graft dysfunction and cholestasis, 3 recovered, and 1 patient was retransplanted successfully (40). At another center, an infant patient with primary graft dysfunction complicating a split liver transplantation was treated with MARS (41). The patient's condition was stabilized until retransplantation 2 weeks later. Six other patients with primary graft dysfunction and bilirubin greater than $15 \mathrm{mg} / \mathrm{dl}$ were treated with MARS (37). Five grafts recovered, eliminating the need for retransplantation. In case reports from two other centers, 2 out of 3 patients were bridged to retransplantation $(42,43)$.

\section{Results in other applications}

As a result of the effectiveness of MARS in removing molecules that accumulate in cholestasis, it has been used to treat a patient suffering from benign recurrent intrahepatic cholestasis. A 36-yearold man suffering for 20 years from attacks of cholestasis lasting 5-6 weeks and associated with intolerable pruritus received 3 single treatments. The pruritus improved clinically faster than in any of the patient's earlier attacks (44). The capability of MARS to increase systemic vascular resistance and mean arterial pressure suggested its use in patients awaiting heart transplantation whose liver failure is complicating ventricular heart failure (45). The treatment resulted in improvement in hepatic encephalopathy and a drop in bilirubin. Whether the treatment can significantly improve the clinical outcome in this group of patients is under investigation in a randomized controlled trial.

\section{DISCUSSION}

The current literature contains evidence that MARS is effective in the treatment of chronic liver disease complicated by hepatorenal syndrome and cholestasis. MARS treatment results in improvement in systemic hemodynamic status, renal function, and hepatic encephalopathy. These changes brought about improvement of the Child Turqotte Pugh score of patients.

The different mechanisms responsible for these improvements are not completely clear. However, the improvement in the outcomes of patients treated with MARS could not only be attributed to removal of bilirubin alone because bilirubin is but an indirect marker for albumin-bound molecules that accumulate in patients with liver failure and is nontoxic. A number of investigators indicate that toxic bile acids are involved in the pathophysiological changes seen in cholestasis and may be even toxic to the liver (46). The reduction of serum bile acid levels by MARS treatment was associated with a reduced toxicity of the plasma of patients if applied to primary hepatocytes in culture (34). Other molecules bound to albumin that may be involved in the clinical effects seen during MARS treatments are endogenous vasodilators such as nitric oxide (47), which has been shown to accumulate in patients with liver failure (48). Whether an endogenous vasodilator is removed by albumin dialysis or albumin dialysis removes molecules that compete with an endogenous vasodilator for binding sites has yet to be examined. The extracorporeal removal of albumin-bound molecules by MARS reduces competitors for serum albumin binding sites, and provides more available binding sites in the microcirculation for binding free toxic molecules.

\section{CONCLUSIONS}

Increasing survival time is the major goal of liver support. The ability of the current MARS technique to prolong significantly survival time in patients with hepatorenal syndrome complicating severe cholestasis has been shown in a prospective, controlled randomized trial. The use of long-term albumin dialysis to support patients awaiting elective liver transplantation in case of decompensation was reported by Seige and colleagues (49). The efficacy and cost ef- 
ficiency of albumin dialysis can be improved by using sorbent-based recycling as done by the MARS technique (50). To date, more than 500 MARS treatments have been done in more than 200 patients. One hundred and three of these patients are reported in the literature. An overview of reported data is given in Table 2. Data from 19 centers reporting on 103 patients show that albumin dialysis using MARS is safe, easy to handle, and feasible. It has been shown to be effective in liver failure com- plicated by hepatic encephalopathy or cholestasis and has been associated with clinical improvement. A prospective, controlled randomized two-center trial has shown that MARS is able to prolong survival time significantly.

Ongoing prospective, randomized, controlled trials elucidating the efficacy and cost-effectiveness of MARS versus standard medical treatment in managing decompensated chronic liver disease are underway to determine whether MARS can shorten

TABLE 2. A summary of multicenter clinical experiences

\begin{tabular}{|c|c|c|c|c|c|c|}
\hline \multirow[b]{2}{*}{ Reference center } & \multicolumn{5}{|c|}{ Reported indications (n) } & \multirow[b]{2}{*}{ Results } \\
\hline & AoC & A & PGD & Other & Total & \\
\hline Awad et al. (36), Michigan & 4 & 5 & & & 9 & $\begin{array}{l}\text { Neurological improvement, bridge to liver } \\
\text { transplant (LTx), reduction of ammonia, } \\
\text { increase of Fischer index and factor VII }\end{array}$ \\
\hline Schmidt et al. $(23,30)$, Copenhagen & 8 & & & & 8 & $\begin{array}{l}\text { Increase of SVR, MAP, and cerebral perfusion, } \\
\text { neurological improvement, decrease of serum } \\
\text { renin activity, bilirubin, ammonia, creatinine }\end{array}$ \\
\hline Sorkin et al. (35), Tel Aviv & 8 & & & & 8 & $\begin{array}{l}\text { Neurological improvement, reduction of } \\
\text { intracranial pressure (ICP), reduction of } \mathrm{SjvO} 2 \text {, } \\
\text { reduction of serum bilirubin, ammonia }\end{array}$ \\
\hline Novelli et al. (37), Rome & & 4 & 6 & & 10 & $\begin{array}{l}\text { Neurological improvement, bridge to LTx, } \\
\text { reduction of serum ammonia, bilirubin, and } \\
\text { INR }\end{array}$ \\
\hline Stange et al. (34), Rostock & 26 & & & & 26 & $\begin{array}{l}\text { Neurological improvement, reduction of ascites, } \\
\text { bilirubin, PT, bile acids, creatinine, and CTP }\end{array}$ \\
\hline Jost et al. (42), Leipzig & 7 & & 1 & $3^{a}$ & 11 & $\begin{array}{l}\text { Bridge to LTx, decrease of PT, increase of choline } \\
\text { esterases }\end{array}$ \\
\hline Delafosse et al. (43), Lyon & 1 & & 2 & $2^{b}$ & 5 & Neurological improvement in chronic patient \\
\hline Siewert-Delle et al. (39), Göteborg & & 1 & & & 1 & $\begin{array}{l}\text { Neurological and hemodynamic improvement, } \\
\text { reduction of ICP and INR, spontaneous } \\
\text { recovery }\end{array}$ \\
\hline Manz et al. (38), Freiburg & & 1 & & & 1 & $\begin{array}{l}\text { Bridge to elective LTx, reduction of serum copper } \\
\text { and bilirubin in acute WD }\end{array}$ \\
\hline Kreymann et al. (26), Munich & & 1 & & & 1 & $\begin{array}{l}\text { Bridge to elective LTx, reduction of serum copper } \\
\text { and bilirubin in acute WD }\end{array}$ \\
\hline Loock et al. (40), Essen & & & 4 & & 4 & $\begin{array}{l}\text { Neurological improvement, graft recovery, } \\
\text { reduction of serum bilirubin }\end{array}$ \\
\hline Kasakow et al. (41), Jena & & & 1 & & 1 & $\begin{array}{l}\text { Bridge to re-LTx in an infant ( } 15 \text { month old } \\
\text { infant), reduction of serum bilirubin }\end{array}$ \\
\hline Aviles et al. (51), Santa Cruz de Tenerife & 3 & & & & 3 & $\begin{array}{l}\text { Neurological improvement, disappearance of } \\
\text { pruritus, reduction of serum bilirubin }\end{array}$ \\
\hline Seige, Kreymann, et al. (49), Munich & 3 & & & & 3 & $\begin{array}{l}\text { Neurological improvement (EEG-monitored), } \\
\text { bridge to elective LTx, reduction of bilirubin }\end{array}$ \\
\hline Oliviero et al. (52), Mercurio et al. (53), Rome & 1 & & & & 1 & $\begin{array}{l}\text { Neurological improvement (decrease in resting } \\
\text { motor threshold), reduction of ammonia, } \\
\text { bilirubin, and bile acids }\end{array}$ \\
\hline Kapoor et al. (54), London & 1 & & & & 1 & $\begin{array}{l}\text { Neurological improvement, reduction of PT and } \\
\text { bilirubin }\end{array}$ \\
\hline Ullerich et al. (55), Münster & 1 & & & & 1 & $\begin{array}{l}\text { Neurological improvement, bridge to elective LTx, } \\
\text { reduction of bilirubin }\end{array}$ \\
\hline Wilmer et al. (56), Leuven & 1 & & & & 1 & $\begin{array}{l}\text { Neurological improvement, reduction of bilirubin, } \\
\text { bile acids, and PT }\end{array}$ \\
\hline Notohamiprodjo et al. (45), Bad Oyenhausen & & & & $7^{c}$ & 7 & Neurological improvement, reduction of bilirubin \\
\hline Huster et al. (44), Leipzig & & & & $1^{d}$ & 1 & Disappearance of pruritus, reduction of bilirubin \\
\hline Total & 64 & 12 & 14 & 13 & 103 & \\
\hline
\end{tabular}

a 1 liver failure posttrauma; 1 Budd Chiari syndrome; 1 liver failure after hepatectomy in hepatocellular carcinoma and hepatitis B.

${ }^{b} 2$ liver failure after hepatectomy.

${ }^{c} 7$ liver failure secondary to right ventricular heart failure.

${ }^{d} 1$ benign recurrent cholestasis (BRC).

A, acute; AoC, acute on chronic; PGD, primary graft dysfunction; MAP, mean arterial pressure; SVR, systemic vascular resistance; $\mathrm{SjvO}$, jugular vein oxygen saturation; ICP, intracranial pressure; INR, international ration; PT, prothrombin time; CTP, Child Turqotte Pugh score; WD, acute Wilson's disease. 
the time to recovery and decrease morbidity and mortality.

Acknowledgments: Studies presented in this paper were supported by grants from the German Ministry for Research and Development and the National Institutes of Health (NIH). The authors would like to thank the following clinicians and researchers for submitting information about the clinical use of MARS, thus helping in giving this overview: S. Awad, Houston; B. Delafosse, Lyon; G. Novelli, Rome; P. Sorkine, Tel Aviv; U. Jost, Leipzig; A. Wilmer, Leuven; H. Ullerich, Munster; D. Kapoor, London; D. Huster, Leipzig; A. Oliviero, Rome; G. Mercurio, Rome; A. Siewert-Delle, Göteborg; T. Manz, Freiburg; L. Kasakow, Jena; M. Notohamiprodjo, Bad Oyenhausen; S. Klammt, Rostock; J. Loock, Essen; J. Aviles, Santa Cruz de Tenerife; and L.E. Schmidt, Copenhagen.

\section{REFERENCES}

1. Opolon P. High-permeability membrane hemodialysis and hemofiltration in acute hepatic coma: experimental and clinical results. Artif Organs 1979;3(4):354-60.

2. Brunner G. What is needed for an artificial liver? In: Nose Y, Kjellstrand C, Ivanovich P, eds. Progress in artificial organs 1985. Cleveland: ISAO Press, 1986.

3. Winchester JF, Ratcliffe JG, Carlyle E, Kennedy AC. Solute, amino acid, and hormone changes with coated charcoal hemoperfusion in uremia. Kidney Int 1978;14(1):74-81.

4. Shiga Y, Fujihara K, Onodera H, Nagata T, Itoyama Y. Complement activation as a cause of transient hypotension during plasmapheresis. Artif Organs 1998;22(12):1067-9.

5. Ueno S, Tanabe G, Hanazono K, Ogawa H, Yoshidome S, Aikou T, Yoshida A. Postoperative management following massive hepatectomy in a patient with Dubin-Johnson syndrome: report of a case. Surg Today 1998;28(12):1274-8.

6. Binimelis J, Bassas L, Marruecos L, Rodriguez J, Domingo ML, Madoz P, Armengol S, Mangues MA, de Leiva A. Massive thyroxine intoxication: evaluation of plasma extraction. Intensive Care Med 1987;13(1):33-8.

7. Preuschof L, Keller F, Bogner U, Reuter E, Offermann G. Plasma exchange and hemoperfusion in iodine-induced thyrotoxicosis. Blood Purif 1991;9(3):164-8.

8. Burman KD, Yeager HC, Briggs WA, Earll JM, Wartofsky L. Resin hemoperfusion: a method of removing circulating thyroid hormones. J Clin Endocrinol Metab 1976;42(1):70-8.

9. Morachiello P, Landini S, Fracasso A, Righetto F, Scanferla F, Toffoletto P, Genchi R, Bazzato G. Combined hemodialysis-hemoperfusion in the treatment of secondary hyperparathyroidism of uremic patients. Blood Purif 1991;9(3):148-52.

10. Dixit V, Chang TMS. In vitro and clinical studies of the removal of cortisol, thyroxine, insulin, and thyroid-stimulating hormone by coated charcoal haemoperfusion. Life Support Syst 1984;2(4):238-44.

11. Kokot F, Nieszporek T. Influence of hemoperfusion on the concentrations of calcitonin, testosterone and cortisol in blood plasma. Artif Organs 1979;3(4):332-5.

12. Ash SR, Blake DE, Carr DJ, Carter C, Howard T, Makowka L. Clinical effects of a sorbent suspension dialysis system in treatment of hepatic coma (the BioLogic-DT). Int J Artif Organs 1992;15(3):151-61.

13. Kramer L, Gendo A, Funk G, Madl C, Falkenhagen D, Gangl A. Clinical experience with artificial liver support in chronic liver failure with encephalopathy. ASAIO J 1997;46(2):211.

14. Falkenhagen D, Strobl W, Vogt G, Schrefl A, Linsberger I, Serner FJ, Schoenhofen M. Fractionated plasma separation and adsorption system: a novel system for blood purification to remove albumin bound substances. Artif Organs 1999; 23(1):81-6.
15. Watanabe FD, Arnaout WS, Ting P, Navarro A, Khalili T, Kamohara Y, Kahaku E, Rozga J, Demetriou AA. Artificial liver. Transplant Proc 1999;31(1-2):371-3.

16. Sussman NL, Kelly JH. Extracorporeal liver support: cellbased therapy for the failing liver. Am J Kidney Dis 1997;30(5 suppl 4):66-71.

17. Stange J, Mitzner S, Ramlow W, Schmidt R, Klinkmann H. Dialysis against an on line recycled albumin circle enables removal of protein bound toxins. Artif Organs 1993;17(9): 809-13.

18. Stange J, Mitzner S. Mass transfer of albumin bound toxins through membranes-comparison between hemofiltration and the MARS-system. ASAIO J 1995;41(1):11.

19. Reimann A, Betz S, Raff M. Removal of albumin bound toxins by extended dialysis. Int J Artif Organs 1995;18:465.

20. Awad S, Rich PB, Kolla S, Younger JG, Reickert CA, Downing VP, Bartlett RH. Characteristics of an albumin dialysate hemodiafiltration system for the clearance of unconjugated bilirubin. ASAIO J 1997;43:M745-9.

21. Stange J, Mitzner S. A carrier-mediated transport of toxins in a hybrid membrane. Safety barrier between a patients blood and a bioartificial liver. Int J Artif Organs 1996;19:677-91.

22. Steiner C, Stange J, Mitzner S, Schmidt R. Role of albumin for transport and distribution of protein bound substances between compartments. Z Gastroenterol Suppl 2001;39:52.

23. Schmidt LE, Sorensen VR, Svendsen LB, Larsen FS, Stange J, Hansen BA. Improvement of systemic vascular resistance and arterial pressure in patients with acute on chronic liver failure during treatment with the molecular adsorbent recycling system. Hepatology 2000;32(4 pt 2):401A.

24. Stange J, Mitzner S, Risler T, Erley CM, Lauchart W, Goehl H, Klammt S, Peszynski P, Freytag J, Hickstein H, Lohr M, Liebe S, Schareck W, Hopt UT, Schmidt R. Molecular adsorbent recycling system (MARS) - A new membrane based blood purification system for bioartificial liver supportclinical results. Artif Organs 1999;23(4):319-30.

25. Peszynski P, Stange J, Mitzner S, Klammt S, MajcherPeszyuska J, Wacke R, Drewelow B, Schmidt R. Removal of benzodiazepine-like substances as a cause of improvement of hepatic encephalopathy during albumin dialysis. Z Gastroenterol Suppl 2001;39:53.

26. Kreymann B, Seige M, Schweigart U, Kopp KF, Classen M. Albumin dialysis: effective removal of copper in a patient with fulminant Wilson disease and successful bridging to liver transplantation: a new possibility for the elimination of protein bound toxins. J Hepatology 1999;31:1-6.

27. Stange J, Mitzner S, Ramlow W, Gliesche T, Hickstein H, Schmidt R. A new procedure for the removal of protein bound drugs and toxins. ASAIO J 1993;39:M621-5.

28. Stange J, Mitzner S, Klammt S, Peszynski P, Freytag J, Hickstein H, Hentschel J, Schulz M. Inhibition of NO synthase by arginine removal by liver support (MARS) seems to be only a cofactor for reversal of hypotension in decompensated liver cirrhosis that seems to be linked more to removal of protein bound toxins. Hepatology 2000;32(4 pt 2):612A.

29. Awad SS, Sawada S, Solded OS, Rich PB, Klein R, Alarcon WH, Wang SC, Bartlett RH. Can the clearance of tumor necrosis factor alpha and interleukin 6 be enhanced using an albumin dialysate hemodiafiltration system? ASAIO J 1999; 45:47-9.

30. Schmidt LE, Svendsen LB, Sorensen VR, Mitzner S, Hansen BA, Larsen FS. The effect of the molecular adsorbent recycling system (MARS) on cerebral perfusion in patients with acute on chronic liver failure and hepatic encephalopathy. Hepatology 2000;32(4 pt 2):612A.

31. Awad S, Soldes O, Sawata S, Rich P, Hirschl R, Bartlett R. Evaluation of an extracorporeal liver assist device using selective hemodiafiltration in an animal model of hepatic failure. ASAIO J 1988;44:90A.

32. Awad S, Hemmila M, Soldes O, Sawata S, Rich P, Mahler S, Gargulinski M, Hirschl R, Bartlett R. A novel stable repro- 
ducible model of hepatic failure in canines. $J$ Surg Res 2000;94:167-71.

33. Mitzner SR, Stange J, Klammt S, Risler T, Erley CM, Bader BD, Berger ED, Lauchart W, Peszynski P, Freytag J, Hickstein H, Loock J, Lohr JM, Liebe S, Emmrich J, Korten G, Schmidt R. Improvement of hepatorenal syndrome with extracorporeal albumin dialysis MARS: results of a prospective, randomized, controlled clinical trial. Liver Transpl 2000;6(3): 277-86.

34. Stange J, Mitzner SR, Klammt S, Freytag J, Peszynski P, Loock J, Hickstein H, Korten G, Schmidt R, Hentschel J, Schulz M, Lohr M, Liebe S, Schareck W, Hopt UT. Liver support by extracorporeal blood purification: a clinical observation. Liver Transpl 2000;6(5):603-13.

35. Sorkine P, Abraham RB, Szold O, Biderman P, Kidron A, Merchav H, Brill S, Oren R. Role of molecular adsorbent recycling system (MARS) in the treatment of patients with acute exacerbation of chronic liver failure. Z Gastroenterol Suppl 2001;39:40-41.

36. Awad SS, Swaniker F, Bartlett RH. Results of a phase I trial evaluating an extracorporeal hepatic support device utilizing albumin dialysis. Z Gastroenterol Suppl 2001;39:22-23.

37. Novelli G, Rossi M, Pretagostini R, Poli L, Peritore D, Di Nicuolo A, Iappelli M, Cortesini R. Use of MARS in the treatment of acute liver failure: preliminary monocentric experience. Z Gastroenterol Suppl 2001;39:39.

38. Manz T, Bisse E, Ochs A, Cicco A, Grotz W. MARS for treatment of fulminant Wilson crisis. Z Gastroenterol Suppl 2001;39:49.

39. Siewert-Delle A, Henriksson BA, Baeckmann L. Albumin dialysis with the MARS for a patient with acute liver failure due to paracetamol intoxication: a case report. $Z$ Gastroenterol Suppl 2001;39:48.

40. Loock J, Treichel U, Gerken G, Broelsch CE, Phillip Th, Heemann U. Treatment of split liver recipients with poor graft function by albumin dialysis (MARS). Z Gastroenterol Suppl 2001;39:18-19.

41. Kasakoff L, Hommann M, Wagner Th, Konig V, Schmidt K, Scheele J. Application of artificial liver support (MARS) after split-liver transplantation in an infant. Z Gastroenterol Suppl 2001;39:50.

42. Jost U, Sehreiter D, Scheibner L, Lamesch P, Hauss J. Continous venovenous hemofiltration with extracorporeal albumin dialysis "MARS" in critically ill patients before and after liver transplantation. Z Gastroenterol Suppl 2001;39:43.

43. Delafosse B, Garnier E, Dumortier J, Boillot O. Edouard Herriot experience with the MARS in 5 patients experiencing hepatic failure. Z Gastroenterol Suppl 2001;39:38.

44. Huster D, Schubert C, Achenbach H, Caca K, Mössner J, Berr F. Successful clinical application of extracorporeal albu- min dialysis in a patient with benign recurrent intrahepatic cholestasis (BRIC). Z Gastroenterol Suppl 2001;39:13-14.

45. Notohamiprodjo M, Banayosy A, Kizner L, Schuller V, Korfer R. One year experience with MARS therapy in patients with multiorgan failure in Cardiac Center Bad Oyenhausen. $Z$ Gastroenterol Suppl 2001;39:51.

46. Miyoshi H, Bronk SF, Roberts PJ, Svingen PA, Faubion WA, Guicciardi ME. Toxic bile salts induce rodent hepatocyte apoptosis via direct activation of Fas. J Clin Invest 1999;103: 137-45.

47. Stamler JS, Jaraki O, Osborne J, Simon D, Keaney J, Vita J, Singel D, Valeri CR, Loscalzo J. Nitric oxide circulates in mammalian plasma primarily as an s-nitroso adduct of serum albumin. Proc Natl Acad Sci USA 1992;89:7674-7.

48. Bomzon A, Blendis LM. The nitric oxide hypothesis and the hyperdynamic circulation in cirrhosis. Hepatology 1994;20: 1343-50.

49. Seige M, Kreymann B, Jeschke B, Schweigart U, Kopp KF, Classen M. Long term treatment of patients with acute exacerbation of chronic liver failure by albumin dialysis. Transplant Proc 1999;31:1371-5.

50. Klammt S, Mitzner S, Stange J, Peszynski P, Freytag J, Steiner C, Adam U, Hopt UT, Schmidt R. Blood purification in excretory liver insufficiency by albumin dialysis: impact of the dialysis membrane. Hepatology 32(4 pt 2):167A.

51. Aviles J, Macia M, Perez F, Moreno A, Navarro JF, Morales S, Medina ML, Aguiar R, Garcia J. Efficacy of MARS in 3 patients with hepatorenal syndrome and hepatic encephalopathy: first experience in Spain. Z Gastroenterol Suppl 2001;39:20-21.

52. Oliviero A, Mercurio G, Pilato F, Accurso A, Saturno E, Pennisi MA, Mignani V, Gaspan R, Gasbarrini A, Di Campli C, Caminiti G, Gentiloni N, Di Lazzaro V. Motor cortex excitability in severe liver failure: effects of Molecular Adsorbents Recycling System. Z Gastroenterol Suppl 2001;39:47.

53. Gaspari R, Pennisi MA, Mignani V, Gasparrini A, Mercurio G, Di Campli C, Conti G, Gentiloni Silveni N, Proietti R. Artificial liver support as a bridge to orthotopic liver transplantation in a case of acute non-alcoholic steatohepatitis (NASH). Z Gastroenterol Suppl 2001;39:15.

54. Jalan R, Kapoor D, Steiner C, Williams R. MARS in decompensated alcoholic liver disease with multiorgan failure. $Z$ Gastroenterol Suppl 2001;39:12.

55. Ullench H, Avenhaus W, Menzel J, Lerch M, Domschke W. Employment of MARS (Molecular Adsorbents Recycling System) for replacement of liver detoxification function up to orthothopic liver transplantation. Z Gastroenterol Suppl 2001;39:46.

56. Wilmer A, Nevens F, Maes B, Yap P. Molecular Adsorbents Recycling System (MARS) for acute on chronic alcoholic hepatitis: a case report. Z Gastroenterol Suppl 2001;39:45. 